\title{
Phytochemical Analysis and Antioxidant Activities of in vivo and in vitro Shoots of Cleome gynandra $\mathrm{L}$
}

\author{
Shanmuganathan T. ${ }^{1}$, Karthikeyan A. V. P. ${ }^{2}$ \\ P.G and Research Department of Botany, Government Arts College (Autonomous), Karur 639 005, Tamilnadu, India
}

\begin{abstract}
Plants can be called as living elixir since they cure almost all types of ailments. Phytochemicals or secondary metabolites are compounds present in plants responsible for the curative properties of them. Free radicals are the causative agents of all forms of metabolic disorders. Nullifying the ill effects of those free radicals can be done through the phytochemicals and secondary metabolites of plant based origin, which will lead to prevent or cure particular disease. The present study deals with the identifying, quantifying of phytochemicals in aqueous, ethanolic extracts of in vivo and in vitro shoots of $C$. gynandra. This study revealed the presence of metabolically active phytochemicals such alkaloids, flavonoids, phenols, tannins, saponins, terpenoids etc. in the tested extracts. This study also exposed the antioxidant activity of aqueous, ethanolic extracts of in vivo and in vitro shoots of C. gynandra through DPPH scavenging method. The ethanolic extracts of in vitro shoots exhibited higher antioxidant activity than all other extracts tested.
\end{abstract}

Keywords: Cleome gynandra, in vivo, in vitro, Phytochemicals, Antioxidant activity.

\section{Introduction}

Cleome gynandra commonly known as cat's whisker and spider flower in English belongs to the family Cleomaceae (previously capparidaceae). It is one of the staple foods in most of the African countries. It has a wide range of medicinal uses and used in traditional systems of medicine all over the world. The medicinal property of the plant is mainly because of the bioactive substances present in, and the most important of these include flavonoids, phenols, saponins, triterpenes and so on. C.gynandra has many scientifically proven medicinal properties such as antidiabetic, anthelmintic and anti microbial, antioxidant, anti-inflammatory, antinociceptive, immunomodulatory, antitumour activity [1]-[8]. All these properties are due to the presence of biologically active phytochemicals present in it. The present study was aimed at identifying and quantifying those phytochemicals and authenticating their medicinal properties through antioxidant study by DPPH scavenging.

\section{Materials and Methods}

\subsection{Plant Material}

The shoots of healthy $C$. gynandra plants were selected from Mayanur and Thanthonimalai, villages of Karur District, Tamilnadu and India. From the healthy explants in vitro plants were produced using MS medium with optimum concentrations of plant growth regulators [9]. The above said plants samples (in vivo and in vitro) were used for the entire study.

\subsection{Preparation of extracts}

The shoots (excluding reproductive parts) of in vivo and in vitro plants of $C$. gynandra were washed thoroughly with running tap water to remove unwanted particles and placed in bamboo plates at room temperature. The shade dried plant samples were packed in soxhlet apparatus for ethanolic extraction (95\% ethanol) and aqueous extraction with distilled water [10]. The yield of aqueous and ethanolic extracts were used for phytochemical and antioxidant studies.

\subsection{Preliminary phytochemical screening}

The phytochemical screening of secondary metabolites present in the aqueous, ethanolic extracts of in vivo and in vitro plants of $C$. gynandra was examined by the standard methods $[11,12]$.

\subsection{Quantitative analysis phytochemicals}

\subsubsection{Estimation of alkaloids}

To $1 \mathrm{ml}$ of extracts $5 \mathrm{ml}$ phosphate buffer ( $\mathrm{pH} \mathrm{4.7)}$ and $5 \mathrm{ml}$ BCG (Bacille Calmette-Guerin) solution were added and shaken well with $4 \mathrm{ml}$ of chloroform. The extracts were collected in a $20-\mathrm{ml}$ volumetric flask and then diluted to adjust volume with chloroform. The absorbance of the complex in chloroform was measured at $470 \mathrm{~nm}$ against blank prepared as above but without extract. Atropine is used as a standard material and compared the assay with Atropine equivalents. The values were expressed as mean \pm SEM [13].

\subsubsection{Estimation of flavonoids}

Total flavonoid content was determined by Aluminium chloride method using catechin as a standard. $1 \mathrm{ml}$ of test sample and $4 \mathrm{ml}$ of water were taken in a volumetric flask (10 ml volume). After $5 \mathrm{~min} 0.3 \mathrm{ml}$ of $5 \%$ Sodium nitrite, $0.3 \mathrm{ml}$ of $10 \%$ Aluminium chloride was added. After 6 min incubation at room temperature, $2 \mathrm{ml}$ of $1 \mathrm{M}$ Sodium hydroxide was added to the reaction mixture. Immediately the final volume was made up to $10 \mathrm{ml}$ with distilled water. The absorbance of the reaction mixture was measured at 510 $\mathrm{nm}$ against a blank spectrophotometrically. Results were expressed as catechin equivalents (mg catechin/g dried extract). The values were expressed as mean \pm SEM [14]

\subsubsection{Estimation of phenoilc compounds}

The total phenolics content in ethanolic and aqueous extracts were determined with Folin- Ciocalteu's reagent (FCR). The extracts were mixed with $0.4 \mathrm{ml} \mathrm{FCR} \mathrm{(diluted} \mathrm{1:10} \mathrm{v/v);}$ 


\section{International Journal of Science and Research (IJSR) \\ ISSN (Online): 2319-7064 \\ Index Copernicus Value (2013): 6.14 | Impact Factor (2015): 6.391}

After $5 \mathrm{~min} 4 \mathrm{ml}$ of sodium carbonate solution was added. The final volume was made up to $10 \mathrm{ml}$ with distilled water and allowed to stand for $90 \mathrm{~min}$ at room temperature. Absorbance of sample was measured against the blank at $750 \mathrm{~nm}$ using a spectrophotometer. A calibration curve was constructed using catechol solutions as standard and total phenolic content of the extract was expressed in terms of milligrams of catechol per gram of dry weight. The values were expressed as mean \pm SEM [13]

\subsubsection{Estimation of saponins}

Ethanolic and aqueous extracts were dissolved separately in $80 \%$ methanol, $2 \mathrm{ml}$ of vanilin in ethanol was added, mixed well and the $2 \mathrm{ml}$ of $72 \%$ sulphuric acid solution was added, mixed well and heated on a water bath at $60^{\circ} \mathrm{c}$ for $10 \mathrm{~min}$, absorbance was measured at $544 \mathrm{~nm}$ against reagent blank. Diosgenin is used as a standard material and compared the assay with diosgenin equivalents. The values were expressed as mean \pm SEM [11]

\subsubsection{Estimation of tannins}

$1 \mathrm{~g}$ of plant sample was dissolved and made up to $50 \mathrm{ml}$ with distilled water in a $50 \mathrm{ml}$ volumetric flask and shaken well. About $5 \mathrm{ml}$ of the above sample was mixed with $2 \mathrm{ml}$ of $0.1 \mathrm{M} \mathrm{FeCl} 3$ in $0.1 \mathrm{M} \mathrm{HCl}$ and $0.008 \mathrm{M}$ potassium ferrocyanide $[\mathrm{K} 4 \mathrm{Fe}(\mathrm{CN}) 6.3 \mathrm{H} 2 \mathrm{O}]$. The absorbance of the sample is measured with a spectrophotometer at $395 \mathrm{~nm}$ wavelength within $10 \mathrm{~min}$. Tannic acid was used as standard and compared the assay with tannic acid equivalaents. The values were expressed as mean \pm SEM [15]

\subsection{In vitro antioxidant activity- DPPH scavenging}

The antioxidant activity of the aqueous, ethanolic extracts of in vivo, in vitro plants of $C$. gynandra and the standard (ascorbic acid) was assessed on the basis of the radical scavenging effect against the stable 1, 1-diphenyl-2picrylhydrazyl (DPPH). DPPH free radical scavenging activities were measured using plant extracts in various concentrations (100-500 $\mu \mathrm{g} / \mathrm{ml}$ ), DPPH solution (methanolic $0.1 \mathrm{mM}$ DPPH) and ascorbic acid (100-500 $\mu \mathrm{g} / \mathrm{ml})$ as standard solution. About $1 \mathrm{ml}$ of DPPH solution was mixed with $1 \mathrm{ml}$ of sample solution and standard solution separately. These solution mixtures were kept in dark for 30 min and optical density was measured at $517 \mathrm{~nm}$ using Spectrophotometer. Methanolic $0.1 \mathrm{mM}$ DPPH solution was used as blank [16]-[18]. The optical density was recorded and $\%$ inhibition was calculated using the formula given below.

$$
\mathrm{A}-\mathrm{B}
$$

Percent (\%) DPPH scavenging activity= -------------- X 100

$$
\text { A }
$$

Where, $\mathrm{A}=$ optical density of the blank and $\mathrm{B}=$ Optical Density of the sample.

\section{Results and Discussion}

\subsection{Preliminary phytochemical screening}

The preliminary phytochemical screening of aqueous extracts of in vivo and in vitro shoots of $C$. gynandra revealed the presence of alkaloids, flavoinoids, phenols, saponins, tannins, terpenoids, anthroquinones, glycosides, aminoacids and carbohydrates. The screening of ethanolic extracts of in vivo and in vitro shoots of $C$. gynandra exposed the presence of alkaloids, flavoinoids, phenols, saponins, tannins, steroids, coumarins and glycosides (Table.1). All these chemicals are biologically active and responsible for the therapeutic values [1], [2].

Table 1: Preliminary phytochemical screening of aqueous, ethanolic extracts of in vivo and in vitro plants of $\mathrm{C}$. gynandra L.

\begin{tabular}{|c|c|c|c|c|c|}
\hline \multirow{2}{*}{ S.No } & \multirow{2}{*}{ Phytochemicals } & \multicolumn{2}{|c|}{ in vivo } & \multicolumn{2}{|c|}{ in vitro } \\
\cline { 3 - 6 } & & $\mathrm{AE}$ & $\mathrm{EE}$ & $\mathrm{AE}$ & $\mathrm{EE}$ \\
\hline 1 & Alkaloids & + & + & + & + \\
\hline 2 & Flavonoids & + & + & + & + \\
\hline 3 & Phenols & + & + & + & + \\
\hline 4 & Saponins & + & + & + & + \\
\hline 5 & Tannins & + & + & + & + \\
\hline 6 & Terpenoids & + & - & + & - \\
\hline 7 & Anthroquinones & + & - & + & - \\
\hline 8 & Steroids & - & + & - & + \\
\hline 9 & Coumarins & - & + & - & + \\
\hline 10 & Glycosides & + & + & + & + \\
\hline 11 & Aminoacids & + & - & + & - \\
\hline 12 & Carbohydrates & + & - & + & - \\
\hline
\end{tabular}

$\mathrm{AE}$ - Aqueous extract, EE - Ethanolic extract, (+) indicates the presence and (-) indicates the absence of phytochemicals.

\subsection{Quantitative analysis phytochemicals}

The alkaloids, flavonoids, phenols, saponins, tannins content of aqueous, ethanolic extracts of in vivo and in vitro plants of $C$. gynandra were estimated through standard procedures [10]-[15]. Among the tested aqueous extracts phytochemical content of in vitro shoots were higher than in vivo shoots. In the same way, phytochemical content in ethanolic extracts of in vitro were also higher than that of in vivo. Amongst the estimated phytochemicals, high amount of phenolics $(97.5 \pm 0.01 \mathrm{mg} / \mathrm{g})$ were observed in ethanolic extracts of in vivo shoots. Other than phenolics all other estimated phytochemicals (alkaloids-19.5 $\pm 0.10 \mathrm{mg} / \mathrm{g}$, flavonoids$45.3 \pm 0.15 \mathrm{mg} / \mathrm{g}$, saponins $-27.7 \pm 0.20 \mathrm{mg} / \mathrm{g}$, tannins-18.4 \pm $0.12 \mathrm{mg} / \mathrm{g}$ ) were more in ethanolic extracts of in vitro shoots. Aqueous extracts of both tested plant samples yielded comparatively lesser quantity of phytochemicals when compared to their ethanolic extracts (Table.2, Fig.1). These compounds were indentified and quantified by many scientists in different extracts of various plants [14],[17].

Table 2: Quantitative analysis of phytochemicals in aqueous, ethanolic extracts of in vivo and in vitro $\mathrm{C}$.

gynandra L.

\begin{tabular}{|c|c|c|c|c|}
\hline \multirow{2}{*}{$\begin{array}{c}\text { Phytochemica } \\
1\end{array}$} & \multicolumn{3}{|c|}{ Phytochemical content (mg/g) } \\
\cline { 2 - 5 } & \multicolumn{2}{|c|}{ in vivo } & \multicolumn{2}{c|}{ in vitro } \\
\cline { 2 - 5 } & $\mathrm{AE}$ & $\mathrm{EE}$ & $\mathrm{AE}$ & $\mathrm{EE}$ \\
\hline Alkaloids & $10.2 \pm 0.80$ & $18.7 \pm 0.40$ & $11.4 \pm 0.12$ & $19.5 \pm 0.10$ \\
\hline Flavonoids & $19.6 \pm 0.40$ & $41.3 \pm 0.21$ & $21.3 \pm 0.13$ & $45.3 \pm 0.15$ \\
\hline Phenols & $55.1 \pm 0.11$ & $97.5 \pm 0.01$ & $59.4 \pm 0.14$ & $90.1 \pm 0.16$ \\
\hline Saponins & $14.3 \pm 0.13$ & $25.2 \pm 0.14$ & $14.9 \pm 0.14$ & $27.7 \pm 0.20$ \\
\hline Tannins & $10.1 \pm 0.10$ & $17.6 \pm 0.12$ & $10.7 \pm 0.11$ & $18.4 \pm 0.12$ \\
\hline
\end{tabular}

$\mathrm{AE}$ - Aqueous extract, EE - Ethanolic extract. All the values in the table were mean of five replicates and were expressed as mean $\pm \mathrm{SEM}$. 
International Journal of Science and Research (IJSR)

ISSN (Online): 2319-7064

Index Copernicus Value (2013): 6.14 | Impact Factor (2015): 6.391

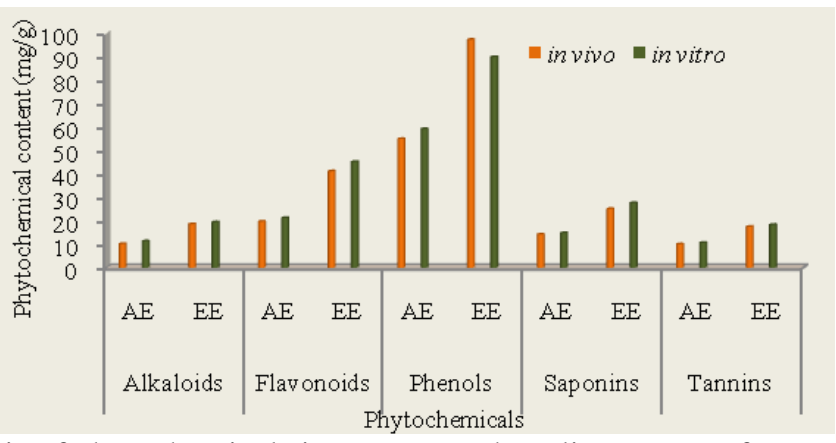

Figure 1: Quantitative analysis of phytochemicals in aqueous, ethanolic extracts of in vivo and in vitro C. gynandra L. $\mathrm{AE}-$ Aqueous extract, EE - Ethanolic extract.

\subsection{In vitro antioxidant activity}

The antioxidant activity of aqueous, ethanolic extracts of in vivo and in vitro plants of $C$. gynandra was studied by scavenging of DPPH. All the tested extracts showed radical scavenging activity in a dose dependant manner. Among the tested extracts, ethanolic extract at a concentration 500 $\mu \mathrm{g} / \mathrm{ml}$ of in vitro shoots produced maximum DPPH scavenging activity of $37.67 \pm 0.91 \%$. When compared to the standard ascorbic acid $(18.96 \pm 0.69 \%)$ all other tested extracts produced maximum radical scavenging activity (Table.3, Fig.2). Similar DPPH scavenging activities of different plant extracts had been observed by different researchers [16]-[18].

Table 3: Antioxidant activity of aqueous, ethanolic extracts of in vivo and in vitro plants of C. gynandra L.

\begin{tabular}{|c|c|c|c|c|c|c|}
\hline \multirow{3}{*}{$\begin{array}{l}\text { S. } \\
\text { No }\end{array}$} & \multirow{3}{*}{$\begin{array}{c}\text { Concentration } \\
\text { of extract } \\
(\mu \mathrm{g} / \mathrm{ml})\end{array}$} & \multicolumn{5}{|c|}{ DPPH scavenging activity (\%) } \\
\hline & & \multicolumn{2}{|c|}{ Aqueous } & \multicolumn{2}{|c|}{ Ethanol } & \multirow{2}{*}{$\begin{array}{l}\text { Ascorbic } \\
\text { acid }\end{array}$} \\
\hline & & in vivo & in vitro & in vivo & in vitro & \\
\hline 1 & 100 & $\begin{array}{c}16.11 \pm \\
0.34\end{array}$ & $\begin{array}{c}18.15 \pm \\
0.67\end{array}$ & $\begin{array}{c}17.21 \pm \\
0.23\end{array}$ & $\begin{array}{c}27.58 \pm \\
0.84\end{array}$ & $15.00 \pm 0.38$ \\
\hline 2 & 200 & $\begin{array}{c}18.25 \pm \\
0.65\end{array}$ & $\begin{array}{c}20.92 \pm \\
0.59\end{array}$ & $\begin{array}{c}20.42 \pm \\
0.41\end{array}$ & $\begin{array}{c}29.97 \pm \\
0.57\end{array}$ & $17.23 \pm 0.86$ \\
\hline 3 & 300 & $\begin{array}{c}19.86 \pm \\
0.28\end{array}$ & $\begin{array}{c}22.12 \pm \\
0.91\end{array}$ & $\begin{array}{c}21.36 \pm \\
0.46\end{array}$ & $\begin{array}{c}32.16 \pm \\
0.69\end{array}$ & $17.86 \pm 0.81$ \\
\hline 4 & 400 & $\begin{array}{c}21.34 \pm \\
0.42\end{array}$ & $\begin{array}{c}25.11 \pm \\
0.78\end{array}$ & $\begin{array}{c}22.90 \pm \\
0.61\end{array}$ & $\begin{array}{c}34.63 \pm \\
0.87\end{array}$ & $18.32 \pm 0.57$ \\
\hline 5 & 500 & $\begin{array}{c}23.48 \pm \\
0.71\end{array}$ & $\begin{array}{c}26.97 \pm \\
0.65\end{array}$ & $\begin{array}{c}27.33 \pm \\
0.43\end{array}$ & $\begin{array}{c}37.67 \pm \\
0.91\end{array}$ & $18.96 \pm 0.69$ \\
\hline
\end{tabular}

All the values in the table were mean of five replicates and were expressed as mean $\pm \mathrm{SEM}$.

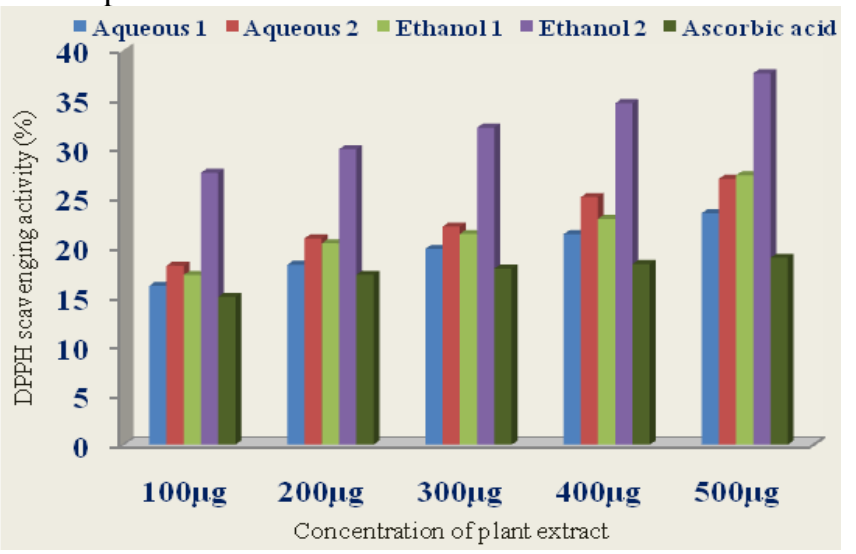

Figure 2: Antioxidant activity of aqueous, ethanolic extracts of in vivo and in vitro plants of $C$. gynandra L.

1 - In vivo, 2 - In vitro

\section{Acknowledgement}

The Corresponding author (Dr. A.V.P. Karthikeyan) is thankful to $U G C$, New Delhi for its financial assistance in the form of major research project.

\section{References}

[1] Karimulla Shaika, Afsar Shaika, Deepak Kumarb, Devi Kadirvel. Evaluation Of Preliminary Phytochemical Properties And Hypoglycemic Activity Of Cleome gynandra L. Int J Pharm Pharm Sci. 2013; 5( 3): 824828.

[2] Ajaiyeoba EO. Phytochemical and Antimicrobial studies of Gynandropsis gynandra and Buchholzia coriaceae extracts. Afr J Biomed. 2000; 3:161-165.

[3] Atawodi SE. Antioxidant potential of African medical plants. Afr J Biotechnol. 2005; 4(2):128-33.

[4] 4. Anbazhagi T, Kadavul K, Suguna G, Petus AJA. Studies on the pharmacognostical and in vitro antioxidant potential of Cleome gynandra Linn. leaves. Nat Prod Rad. 2009; 8(2):151-57.

[5] Narendhirakannan RT, Subramanian S, Kandaswamy M. Anti-inflammatory and lysosomal stability action of Cleome gynandra L. studied in adjuvant induce arthritic rats. Food Chem Toxicol. 2007; 45(6):1001-12.

[6] Ghogare UR, Nirmal SA, Patil RY, Kharya MD. Antinociceptive activity of Gynandropsis gynandra leaves. Nat Prod Res .2009; 23(4):327-33.

[7] Kori ML, Gaur K, Dixit VK. Andra investigation of immunomodulatory potential of Cleome gynandra. Asian Journal of Pharmaceutical and Clinical Research. 2009; 2(1):35-39.

[8] Asis Bala, Biswakanth Kar, Pallab.K, Haldar, Upal K, Mazumder, Samit Bera. Evaluation of anticancer activity of Cleome gynandra on Ehrlich's Ascites carcinoma treated mice. J Ethnopharmacol. 2010; 129:131-34.

[9] Karthikeyan, A.V.P., Shanmuganathan, T. and Karthi, C. 2014. In vitro propagation of Cleome gynandra L. through direct organogenesis. IJSR. 3 (7): 1368-1372.

[10] Anokbonggo, W.W. 1975. Extraction of pharmacologically active constituents of the roots of Phytolacca dodecandra. J Plant Medica. 28: 69-75.

[11] Obadoni, B.O. and Ochuko, P.O. 2001. Phytochemical studies and comparative efficacy of the crude extracts of some homeostatic plants in Edo and Delta States of Nigeria. Global Journal of Pure and Appllied Science. 8(2): $203-208$. 


\section{International Journal of Science and Research (IJSR) \\ ISSN (Online): 2319-7064}

Index Copernicus Value (2013): 6.14 | Impact Factor (2015): 6.391

[12] Waterman, P.G. 1993. Methods in Plant Biochemistry. Acad. Press. Vol.8.

[13] Harborne, J.B. 1998. Phytochemical methods: A guide to modern techniques of plant analysis. $3^{\text {rd }}$ ed. Chapman and Hall Int. (Ed).NY. 49-188.

[14]Zhishen, J., Mengcheng, T. and Jianming, W. 1999. The determination of flavonoid contents in mulberry and their scavenging effects on superoxide radicals. Food Chemistry. 64: 555-559.

[15] Van-Burden, T. and Robinson, W. 1981. Formation of complexes between protein and Tannin acid. J. Agric. Food Chem. 1-77.

[16]Bors, W., Saran, M. and Elstner, E.F. 1992. Screening for plant anti-oxidants. In: Linskens HF, Jackson JF. eds. Modern Methods of Plant Analysis-Plant Toxin Analysis. 1992; 13: 277-295.

[17] Bala, A., Karmakar, I. and Haldar, P.K. 2012. Isolation and HPLC characterization of the flavanoid fractions from Cleome gynandra and comparative antioxidant activity. Recent Progress in Medicinal Plants. 32: 226240.

[18] Braca, A., Sortino, C. and Politi, M. 2002. Anti-oxidant activity of flavonoids from Licania licaniaeflora. Journal of Ethnopharmacology. 79: 379 - 381.

\section{Author Profile}

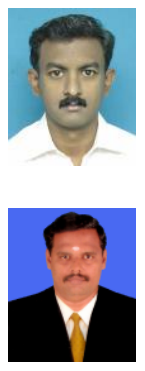

T. Shanmuganathan, a part time research scholar and working as BT Assistant in Science at P.U.M.School, Kattur, Karur Dist. He received academic proficiency medal for his UG \& PG course at St. Joseph's college, Tiruchirappalli.

Dr. A.V.P. Karthikeyan, Plant Biotechnologist has specialized in Plant Tissue Culture. He did his Ph. D. in Botany (2001) from Bharathidasan University, Tiruchirappalli and M. Sc. in Botany (1996) from St. Joseph's College, Tiruchirappalli, Tamil Nadu, India. Currently he is working as an Assistant Professor in P.G. \& Research Department of Botany, Government Arts College, Karur, Tamil Nadu, India from 2007 and Principal Investigator of UGC funded Major Research Project, UGC, New Delhi. 